\title{
Resolution of Long-Standing Diabetes Mellitus Two Years After Surgery for Growth Hormone Producing Pituitary Tumor
}

This article was published in the following Dove Press journal:

International Medical Case Reports Journal

\section{Poorna Gopal Azad \\ Sreeramaneni $\mathbb{D I}^{\prime}$ \\ Rajesh K Ghanta ${ }^{2}$ \\ 'Department of Endocrinology, Sreeramaneni Sumanth Krishna Endocrinology, Diabetes and Thyroid Hospitals, Vijayawada, India; ${ }^{2}$ Department of Neurosurgery, Suraksha Hospitals, Vijayawada, India}

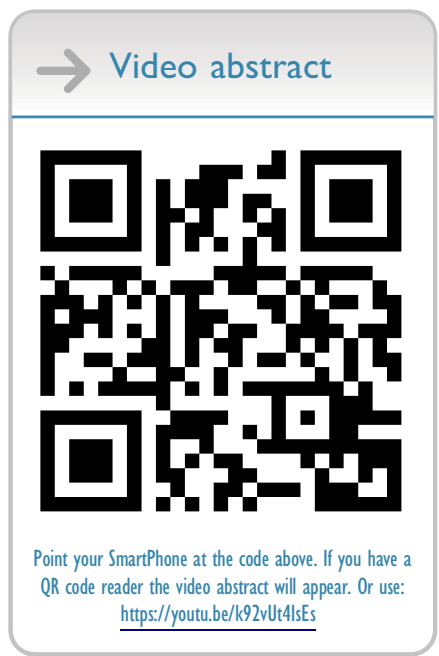

Correspondence: Poorna Gopal Azad Sreeramaneni

Department of Endocrinology,

Sreeramaneni Sumanth Krishna

Endocrinology, Diabetes and Thyroid

Hospitals, Vijayawada 520002, India

Tel +9l 8662436I56

Email drpurnagopal@gmail.com

\begin{abstract}
Excess serum growth hormone $(\mathrm{GH})$ induces insulin resistance leading to reduced uptake of glucose in peripheral tissues, gluconeogenesis in the liver and lipolysis and finally an increase in the blood glucose levels. We report a case where a 54-year-old woman presented with uncontrolled blood glucose levels since 5 years. On examination, she had signs and symptoms consistent with acromegaly including recurrent headaches, sleep apnea, soft tissue swelling, enlargements of the feet, hands, ears and lips, mandibular overgrowth, forehead protrusio and teeth spacing. She was on oral hypoglycemic agents (OHAs) for 12 years before she visited our hospital, but the blood glucose levels have been uncontrolled for the past 5 years with recurrent hyperglycaemic and occasional hypoglycaemic events. She underwent pituitary surgery for GH producing tumor and 2 years post surgery, we had to stop all the medications for the diabetes mellitus. This indicates that even long-standing diabetes mellitus can resolve in some patients with acromegaly.
\end{abstract}

Keywords: diabetes control in growth hormone pituitary tumor, surgery for growth hormone producing pituitary tumor

\section{Learning Points}

Once the diagnosis of acromegaly is made, it is recommended to increase the dose of insulin sensitizers like metformin and reduce the dose of sulfonylureas like glimepiride to preserve the pancreatic beta cell mass to make it possible in future to stop the medications directed towards controlling blood glucose levels completely. ${ }^{1}$

Even for patients with long-standing diabetes mellitus in acromegaly, it is possible to stop the anti-diabetic medications within few years after the removal of GH producing tumor.

In patients with very high $\mathrm{GH}$ levels at the time of diagnosis $(>40 \mathrm{ng} / \mathrm{mL})$, second pituitary surgery might be required even after a successful surgery to meet the required results.

Dopamine agonists like cabergoline might be required to reduce the IGF-1 levels along with pituitary surgery.

\section{Background}

In this patient, the acromegaly was undiagnosed for several years. The patient informed that the changes in the face, suggestive of acromegaly, started around 10 years before she was finally diagnosed of the condition. At the time of diagnosis, 


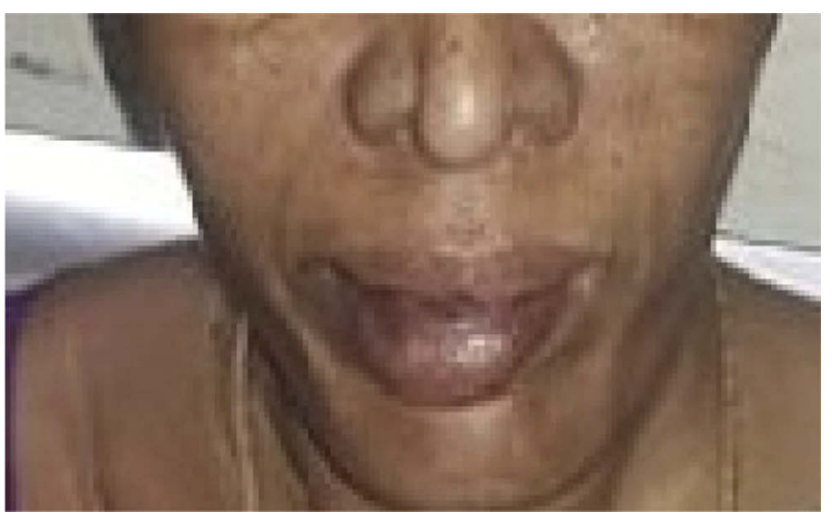

Figure I Unusually thick lips and mandibular overgrowth.

the serum GH levels were more than $40 \mathrm{ng} / \mathrm{mL}$. The $\mathrm{GH}$ testing was done through chemiluminescence method.

\section{Case Presentation}

A 54-year-old woman presented with uncontrolled blood glucose levels with history of diabetes mellitus since 12 years. Her blood glucose levels have been uncontrolled since 5 years with $\mathrm{HbAlC}$ at the time of the diagnosis of acromegaly at around $12 \%$. Her facial features like mandibular overgrowth, unusually thick lips (see Figure 1), forehead protrusion, and other signs like enlarged hands and feet raised the suspicion of acromegaly ${ }^{2,3}$ in which the pituitary produces an excess of growth hormone. High serum growth hormone levels cause insulin resistance, gluconeogenesis in the liver and lipolysis leading to uncontrolled blood glucose levels. ${ }^{4,5}$ As the serum growth hormones levels increase so do the blood glucose levels.

\section{Investigation}

Growth Hormone levels were high at $>40 \mathrm{ng} / \mathrm{mL}$ at the initial visit. OGTT suppression test was done and the fasting $\mathrm{GH}$ levels were $>40 \mathrm{ng} / \mathrm{mL}, 38.6 \mathrm{ng} / \mathrm{mL}$ at 1 hrs and $38.7 \mathrm{ng} / \mathrm{mL}$ at $2 \mathrm{hrs}$ after the administration of $100 \mathrm{~g}$ of glucose.

IGF1 levels were elevated at $783 \mathrm{ng} / \mathrm{mL}$ (normal value: 94-252 ng/mL)

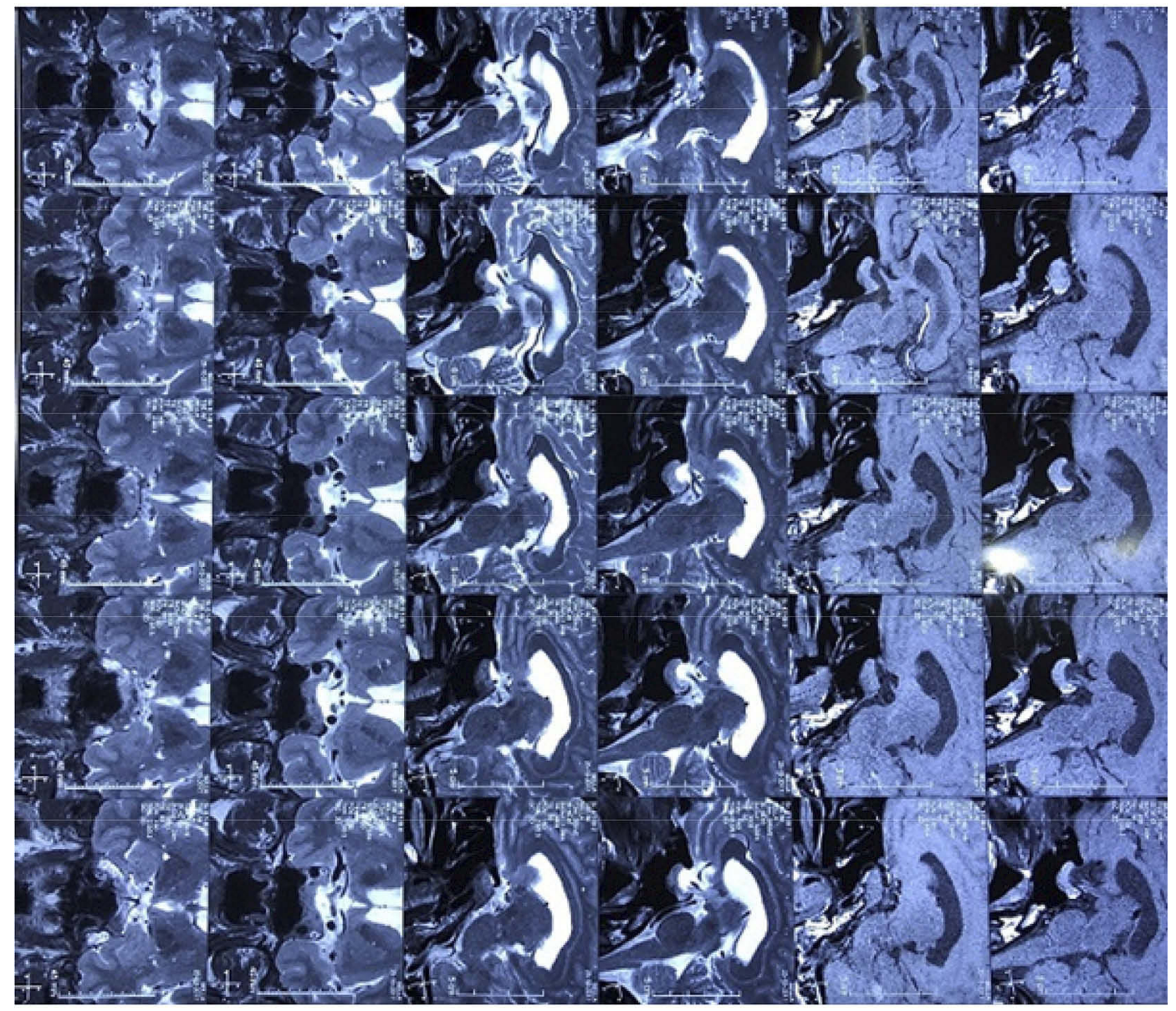

Figure $2 \mathrm{MRI}$ of the pituitary and the brain. Film number one. 


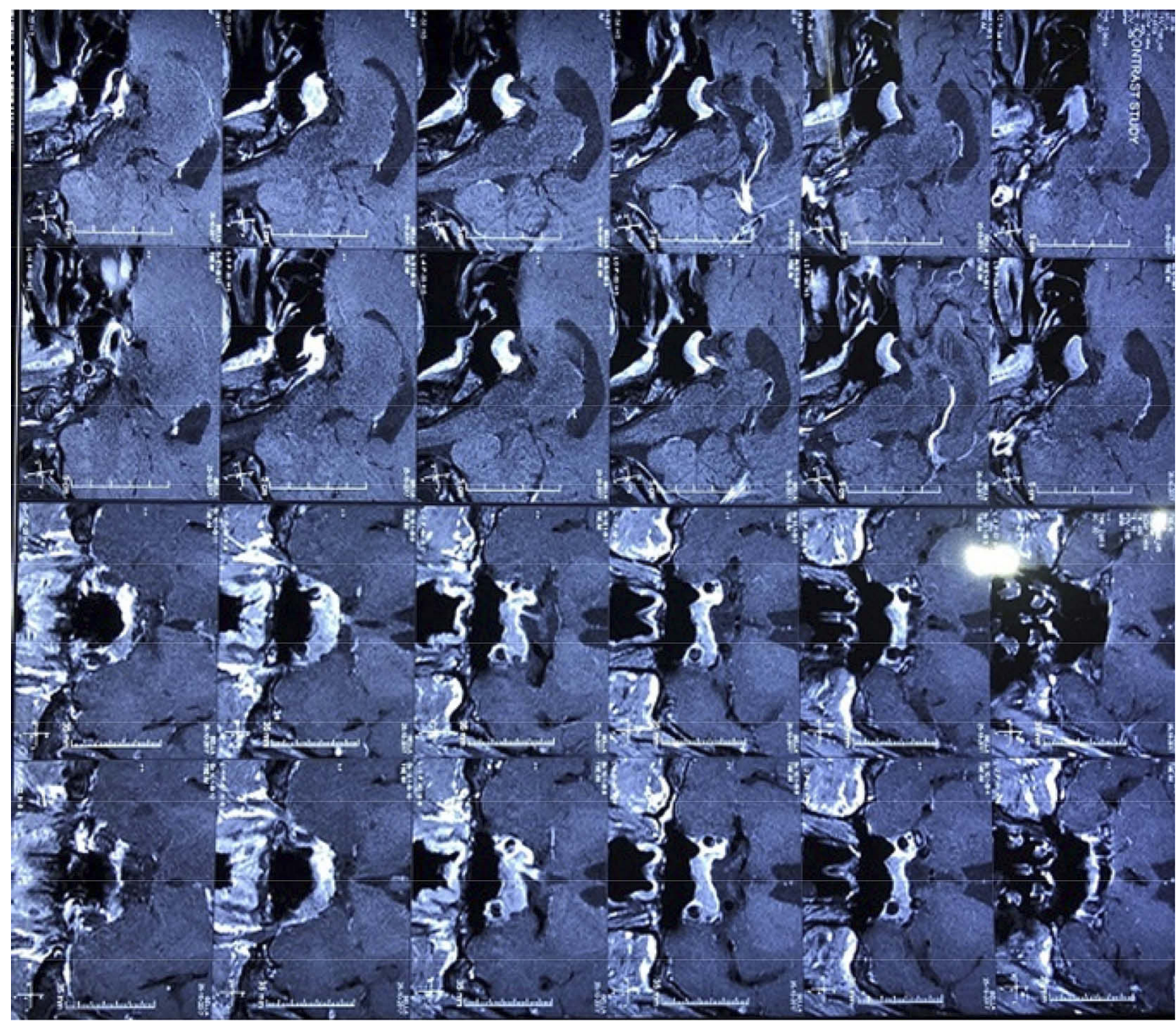

Figure $3 \mathrm{MRI}$ of the pituitary and the brain. Film number two.

Prolactin was $3.98 \mathrm{ng} / \mathrm{mL}$ and $\mathrm{LH}$ was $12.3 \mathrm{mIU} / \mathrm{mL}$. ACTH $(45 \mathrm{pg} / \mathrm{mL})$ and cortisol $(9.94 \mathrm{mcg} / \mathrm{dl})$ levels were also within the normal ranges. HbAlc level was $12 \%$. Fasting blood glucose level was $248 \mathrm{mg} / \mathrm{dl}$ and postprandial blood glucose level was $322 \mathrm{mg} / \mathrm{dl}$.

MRI of pituitary revealed asymmetrical enlargement of the anterior pituitary gland on the left side with the involvement of the left cavernous sinus (see Figures 2 and 3).

\section{Treatment and Outcome}

Pituitary surgery was performed in November 2017 by Endoscopic Endonasal approach with excision of the pituitary macroadenoma. Three months post-surgery, the GH levels reduced from $>40 \mathrm{ng} / \mathrm{mL}$ to $21.8 \mathrm{ng} / \mathrm{mL}$. MRI pituitary, which was repeated 3 months post-surgery, showed a residual mass towards left side of the sella abutting the left ICA and showing homogenous enlargement. Second pituitary surgery was performed 4 months after the first surgery. After the second surgery on the pituitary, cabergoline was initiated at $0.5 \mathrm{mg}$ once weekly to aid in reducing the GH levels which was later decreased to $0.5 \mathrm{mg}$ once weekly and was completely stopped after 1 year. Dopamine agonists like cabergoline are effective and well tolerated treatment in acromegaly in lowering the serum GH levels. ${ }^{12}$

During the time of surgery, the blood glucose levels have been controlled with insulin therapy and metformin. Blood glucose levels were maintained below $180 \mathrm{mg} / \mathrm{dl}$. Serum growth hormone levels were tested every 3 months for 2 years.

Three months after the second surgery, the serum GH level further lowered to around $14 \mathrm{ng} / \mathrm{mL}$. Blood glucose levels were controlled with insulin therapy thrice daily which was reduced to twice daily later on along with metformin $1 \mathrm{~g}$ twice daily. At much later stage the blood glucose levels were controlled with metformin, sitagliptin and insulin once daily instead of twice daily. The HbA1c levels reduced from $12 \%$ at the initial diagnosis of acromegaly to $6.4 \%$ (Table 1) two years post surgery. It took almost 2 years since the first surgery on the pituitary for the serum GH levels to reduce to $7 \mathrm{ng} / \mathrm{mL}$ (Table 2). At 
Table I Growth Hormone Levels Timeline

\begin{tabular}{|l|l|}
\hline $\mathrm{GH}$ levels at the initial visit and diagnosis & $>40 \mathrm{ng} / \mathrm{mL}$ \\
\hline $\mathrm{GH}$ levels 3 months after the $1^{\text {st }}$ surgery & $21.8 \mathrm{ng} / \mathrm{mL}$ \\
\hline $\mathrm{GH}$ levels 3 months after the $2^{\text {nd }}$ surgery & $14 \mathrm{mg} / \mathrm{mL}$ \\
\hline GH levels 2 years after the first visit to the hospital & $07 \mathrm{ng} / \mathrm{mL}$ \\
\hline
\end{tabular}

Table 2 HbAlc Levels Timeline

\begin{tabular}{|l|l|}
\hline $\mathrm{HbAlc}$ levels at the initial visit & $12 \%$ \\
\hline $\begin{array}{l}\text { HbAIc } 3 \text { months after the Is }{ }^{\mathrm{t}} \text { surgery with insulin } \\
\text { replacement and metformin }\end{array}$ & $8 \%$ \\
\hline $\begin{array}{l}\text { HbAlc } 3 \text { months after the 2nd surgery with insulin } \\
\text { replacement and metformin }\end{array}$ & $7.4 \%$ \\
\hline $\begin{array}{l}\text { HbAlc } 2 \text { years after the Ist visit and } 3 \text { months after stopping } \\
\text { all the medications directed towards diabetes mellitus }\end{array}$ & $6.4 \%$ \\
\hline
\end{tabular}

this stage, all the medications directed towards the control of blood glucose levels including insulin and oral medications were stopped due to repeated incidents of hypoglycemia. Even after stopping all the medications for diabetes mellitus, the blood glucose levels have been well controlled with fasting blood glucose at around $130 \mathrm{mg} / \mathrm{dl}$ and postprandial blood glucose around $160 \mathrm{mg} / \mathrm{dl}$ and $\mathrm{HbA} 1 \mathrm{C}$ of around $6.4 \%$.

\section{Discussion}

Acromegaly is rare and occurs in around 2.8 to 13.7 per 100,0000 people. ${ }^{6}$ Diabetes mellitus is present in around $12-37 \%$ of patients with acromegaly. ${ }^{7}$ High serum growth hormone levels lead to high blood glucose state because of high insulin resistance, gluconeogenesis and also lipolysis. Patients with acromegaly can also develop ketoacidosis. In fact in some patients with acromegaly, diabetic ketoacidosis can be the presenting complaint before the diagnosis of acromegaly is made. ${ }^{10}$ Hormones like glucagon, adrenaline, cortisol and growth hormone antagonize the insulin effect on blood glucose levels and thereby increasing the blood glucose levels. ${ }^{8,9}$ Also, growth hormone increases the blood glucose levels through gluconeogenesis. ${ }^{11}$ As the patients GH levels kept increasing over the years, blood glucose levels in this patient also kept fluctuating with high HbAlc levels for 5 years before the acromegaly was diagnosed. Once the GH levels reduced to around $7 \mathrm{ng} / \mathrm{mL}$, the medications directed towards diabetes mellitus had to be completely stopped, This indicates in some cases of acromegaly where there is very high production of $\mathrm{GH}$, even long-standing diabetes mellitus might resolve in some cases after drastic reduction in the $\mathrm{GH}$ levels. It took more than 2 years for the medications directed towards diabetes mellitus to be stopped in this patient.

Also, some signs and symptoms which were present at the time of diagnosis of acromegaly like sleep apnea, hypertension, recurrent headaches and soft tissue swelling have subsided. However, skull deformities like cranial thickening did not show much improvement which is usually seen in many patients of acromegaly even if their GH levels have drastically reduced. ${ }^{14}$

Though most cases of Acromegaly are benign and nonaggressive, some can behave aggressively compromising local surrounding structures. These tumors tend to recur after the pituitary surgery and respond poorly to the somatostatin analogs. ${ }^{13}$ Treatment with somatostatin analogs bound with ${ }^{90}$ Y-DOTATATE maybe an option for aggressive tumors not responding to other methods. ${ }^{15}$

\section{Patient Consent}

Oral consent has been obtained from the patient and written informed consent has been provided by the patient's family to have the case details and any accompanying images published.

\section{Ethics Approval}

Institutional review board approval is not required at our institution. Name of the patient has not been mentioned in the paper. The patient received treatment according to the current standard of care.

\section{Acknowledgments}

We would like to extend special thanks to Dr Benjamin Glaser and Dr Dresner Rivka Polak of Department of Endocrinology and Metabolism, Hadassah Medical Centre, Ein Kerem, Jerusalem, Israel. We also thank Dr Navya Sriramaneni, Ms Aishwarya Sreeramaneni and Mrs Gandharva Rani Sreeramaneni, MA who helped us in preparing this article.

\section{Author Contributions in the Treatment}

Dr Poorna Gopal Azad Sreeramaneni, Endocrinologist, first diagnosed the acromegaly in the patient and followed the blood glucose levels and growth hormone levels. Dr Rajesk K Ghanta, senior Neurosurgeon, performed the two 
surgeries on the pituitary and also followed up the growth hormone levels along with Dr Poorna.

\section{Funding}

This research did not receive any specific grant from any funding agency in the public, commercial or not-for-profit sector.

\section{Disclosure}

There is no conflict of interest that could be perceived as prejudicing the impartiality of the research reported.

\section{References}

1. Page KA, Reisman T. Interventions to preserve beta-cell function in the management and prevention of type 2 diabetes. Curr Diab Rep. 2013;13(2):252-260. doi:10.1007/s11892-013-0363-2

2. Acromegaly. Available from: https://www.niddk.nih.gov/healthinformation/endocrine-diseases/acromegaly. Accessed January 18,2020 .

3. Dineen R, Stewart PM, Sherlock M. Acromegaly. QJM Int J Med. 2017;110(7):411-420. doi:10.1093/qjmed/hcw004

4. Takano A, Haruta T, Iwata M, et al. Growth hormone induces cellular insulin resistance by uncoupling phosphatidylinositol 3-kinase and its downstream signals in 3t3-11 adipocytes. Diabetes. 2001;50:1891-1900. doi:10.2337/diabetes.50.8.1891

5. Vila G, Jørgensen JO, Luger A, Stalla GK. Insulin resistance in patients with acromegaly. Frontiers in Endocrinology. 2019;10. doi: $10.3389 /$ fendo.2019.00509
6. Lavrentaki A, Paluzzi A, JA W, Karavitaki N. Epidemiology of acromegaly: review of population studies. Pituitary. 2017;20(1):4-9. doi:10.1007/s11102-016-0754-x

7. Hannon AM, Thompson CJ, Sherlock M. Diabetes in Patients With Acromegaly. Curr Diab Rep. 2017;17(2):8. doi:10.1007/s11892-0170838-7

8. Møller N, Jørgensen JO. Effects of growth hormone on glucose, lipid, and protein metabolism in human subjects. Endocr Rev. 2009;30 (2):152-177. doi:10.1210/er.2008-0027

9. Smith U, Attvall S, Eriksson J, Fowelin J, Lönnroth P, Wesslau C. The insulin-antagonistic effect of the counterregulatory hormones clinical and mechanistic aspects. In: Östenson CG, Efendić S, Vranic M, editors. New Concepts in the Pathogenesis of NIDDM. Boston, MA: Springer; 1993. doi:10.1007/978-1-4615-2910-1_12

10. Simmons LR, Hughes K, Markovic TP, Elizabeth L. Patients with acromegaly also develop ketoacidosis. Chua Clin Diabetes. 2012;30 (4):170-172. doi:10.2337/diaclin.30.4.170

11. Vijayakumar A, Yakar S, LeRoith D. The intricate role of growth hormone in metabolism. Front Endocrinol. 2011;2. doi:10.3389/ fendo.2011.00032.

12. Abs R, Verhelst J, Maiter D, et al. Cabergoline in the treatment of acromegaly: a study in 64 patients. J Clin Endocrinol Metab. 1998;83 (2):374-378. doi:10.1210/jcem.83.2.4556

13. Carrasco CA, Gadelha M, Manavela M, et al. Aggressive tumors and difficult choices in acromegaly. Pituitary. 2014;17 Suppl 1(Suppl 1): S24-S29. doi:10.1007/s11102-013-0538-5

14. Rick JW, Jahangiri A, Flanigan PM, Aghi MK. Patients cured of acromegaly do not experience improvement of their skull deformities. Pituitary. 2017;20:292-294. doi:10.1007/s11102-0160741-2

15. Waligórska-Stachura J, Gut P, Sawicka-Gutaj N, et al. Growth hormone-secreting macroadenoma of the pituitary gland successfully treated with the radiolabeled somatostatin analog 90Y-DOTATATE: case report. J Neurosurg. 2016;125:346-349. doi:10.3171/2015.6. JNS15363

\section{Publish your work in this journal}

The International Medical Case Reports Journal is an international, peer-reviewed open-access journal publishing original case reports from all medical specialties. Previously unpublished medical posters are also accepted relating to any area of clinical or preclinical science. Submissions should not normally exceed 2,000 words or 4 published pages including figures, diagrams and references. The manuscript management system is completely online and includes a very quick and fair peer-review system, which is all easy to use. Visit http://www.dovepress.com/testimonials.php to read real quotes from published authors. 